\title{
WHAT INSPIRED THE VEKERZUG POTTERY?
}

\author{
Jan Bouzek
}

DOI: https://doi.org/10.31577/szausav.2019.suppl.1.3

Keywords: pottery, Vekerzug, Early Iron Age, grey ware, coarse ware, Balkans

\section{What inspired the Vekerzug pottery?}

The note discusses the question of models of the Vekerzug wheel-made pottery known from the northwestern Black Sea region and the eastern Balkans, both wheel and hand-made. The explanation of this phenomenon may be found in transmission of technique and shapes of the various Aegean "Aiolian" grey wares and the coarse ware produced in Greece and northwestern Anatolia. Such models could not be found in the fine wares. The Vekerzug pottery shapes and their eastern inspirations were earlier and more sophisticated than the Braubach group in the west, but on a more general level both of them were, similarly as metal objects, part of the more general koine connecting the continental and Mediterranean cultures of the Early Iron Age.

In my book on the Early Iron Age relations (Bouzek 1997, 194-200, 232-244) I was able to follow relations between the Hallstatt culture and the East in realm of bronze and iron objects only. However, with the progress in the field in general, looking more closely it was possible to identify such relations even in the field of pottery. These include for example the new study of Hallstatt period in Eastern Slovakia (Miroššayová 2017), and other papers published in a splendid Archaeolingua Series volume edited by E. Miroššayová, Ch. Pare and S. Stegmann-Rajtár (2017), including studies on the western part of the Carpathian Basin (Metzner-Nebelsick 2017; Stegmann-Rajtár 2017), together with progress in the field of North Aegean and East Balkan grey and related wares (esp. Avram et al. 2009), North-West Anatolian grey wares (Gebauer 1993; Chabot Aslan 2009) and a comparison with the situation of the so-called Braubach ware in the west (Bouzek et al. 2017), which came later to Bohemia than the Vekerzug pottery. All these enable now to bring renewed attention to questions suggested previously esp. by P. Alexandrescu (2000) and P. Romsauer (1991). There was already some knowledge of the Mediterranean civilisation in the temperate climatic zone of Europe, and this note intends to bring attention to this field of study, also as memory of the nice days which I spent on several occasions in the friendly city of Košice.

Interestingly, the basic links showing some inspiration and relation between the first wheel-made pottery in the northeastern and northern Balkans can be seen not in the fine tableware, but in the medium or coarse ware shapes, which were less sophisticated and nearer to the technique used generally by the northern potters. There is the family of the grey wares (Alexandrescu 1978; and esp. Alexandrescu 2000, 138-173), concentrating in particular in the northwestern corner of the Black Sea region, an area with early relations with the Aegean (Bouzek 1990, 13-17; 2011; 2013; Kopylov 2009; Sirbu/Niculifä/Vanciugov 2005; Vančugov 2001). Indirectly important are in this respect also results of chemical analyses conducted mainly on the imported pottery at Histria (Coja/Dupont 1979; Cook/Dupont 1998; Dupont 1983; 2001; Dupont/Baralis 2014). Another link was likely across western Bulgaria (Božkova 2002; 2005; 2015; Catling 1998; later pottery Bouzek 2002; 2003) and along the Black Sea coast in general (Avram et al. 2009; Bayne 2000; Bouzek/Domaradzka 2009; Domaradzki 2002; from Apollonia Božkova/Nikov 2004/2006; Nikov 2012).

Then there is the cruder variety from Transylvania, which is often hand-made (Crişan 1969; Moscalu 1983), with the pottery of the Vekerzug culture usually of finer character (Miroššayová 2017; Romsauer 1991), but some specific shapes of kitchen ware show also reflections of plain wares from Greek cities in the northern Aegean and even in Classical and Hellenistic Greece (Blondé 2007; Rotroff 2006; Sparkes/Talcot 1970). Some of the latter were also popular for their specific contents, but we do not have enough results of chemical analyses in this respect. The few we do have until now, seem to show that the diet in all 
comparable areas was similar to the traditional diet within these areas until modern times. Though with local specifics and differences, Hallstatt Europe had some general phenomena reflecting their functional and formal counterparts in the Aegean and Black Sea, including some kind of general knowledge about even the more distant neighbours.

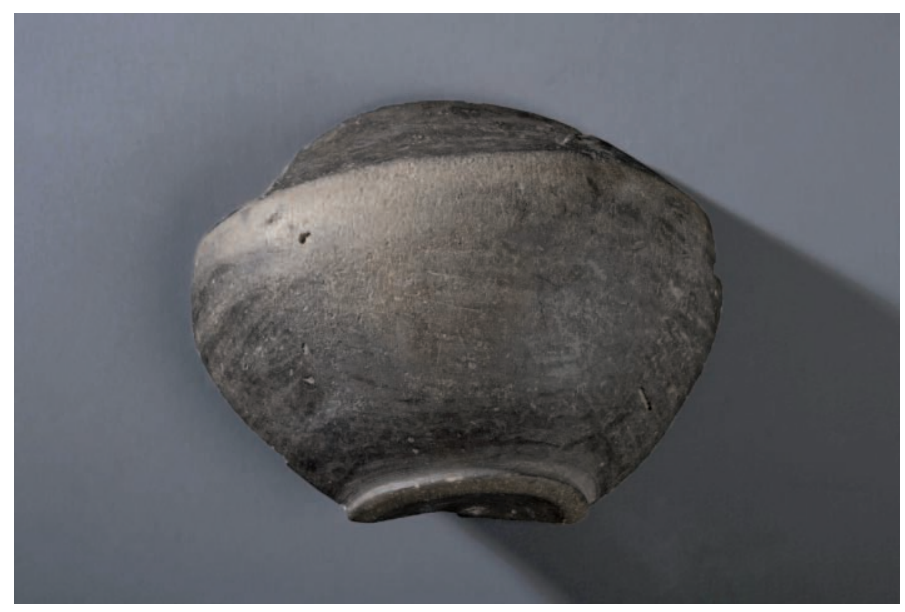

Fig. 1. Fragmentary Vekerzug amphora from Minice (photo courtesy V. Čistáková).

The previous papers by the jubilee on Urnfield roots of the Hallstatt culture in eastern Slovakia (Miroššayová 1998) suggest a hope that such area of study might find an attraction in the field of her interest. In Bohemia the Vekerzug ware is well represented at Minice (Fig. 1), a hillfort in Central Bohemia, with interesting stone structures at the acropolis and with presence of other exotic finds such as worked pieces of coral (Trefný/Slabina 2015, 56-59, fig. 8; 9: 8).

The existing puzzle of the previous discussion may best be explained in the frame of more detailed study of the grey ware in its varieties, known in the Aegean as the Aeolian ware and some facies of the coarse or kitchen wares. The links between them and transfer of technique and shape was easier than in the field of more sophisticated glazed wares; to some extent the koine of Early Iron Age was expressed not only in the field of metal objects, but in that of pottery as well. In the Vekerzug pottery it preceded the rise of the so-called Braubach ware, whose shapes were less sophisticated.

\section{REFERENCES}

Alexandrescu 1978

Alexandrescu 2000

Avram et al. 2009

Bayne 2000

Blondé 2007

Bouzek 1990

Bouzek 1997

Bouzek 2002

Bouzek 2003

Bouzek 2011

Bouzek 2013
P. Alexandrescu: Histria IV. La céramique de l'époque archaïque et classique. Bucuresti - Paris 1978.

P. Alexandrescu: Les modèles grecs de la céramique thrace tournée. In: L'aigle et le dauphin. București 1999, 138-173.

A. Avram et al. (eds.): Pontic Grey Wares 2009. International Conference. Bucarest-Constantza September $30^{\text {th }}$-October $3^{\text {rd }}$ 2008. Pontica 42. Suppl. 1. Constanţa 2009.

N. Bayne: The Grey Wares of North-West Anatolia in the Middle and Late Bronze Age and the Early Iron Age and their Relation to the Early Greek Settlements. Asia Minor Studien 37. Bonn 2000.

F. Blondé: Les céramiques d'usage quotidien à Thasos au IV siècle avant J.-C. Etudes Thasiennes 20. Paris 2007.

J. Bouzek: Studies of Greek Pottery in the Black Sea Area. Prague 1990.

J. Bouzek: Greece, Anatolia and Europe : Cultural Interrelations during the Early Iron Age. Studies in Mediterranean Archaeology 122. Jonsered 1997.

J. Bouzek: The North Greek Wheel-Made glazed pottery in Pistiros. Part I: Classification and possible sources. In: J. Bouzek/L. Domaradzka/Z. H. Archibald (eds.): Pistiros 2: Excavations and Studies. Prague 2002, 149-182.

J. Bouzek: A survey of unglazed and plain pottery from Adžijska Vodenica II, Oikos A. Studia Hercynia 7, 2003, 5-70.

J. Bouzek: The Belozerka fibulae in a broader context. Tyragetia, Serie Nouă 1 (20), 2011, 247-254.

J. Bouzek: Pre-colonisation in the Black Sea. In: G. R. Tetskhladze/S. Atasoy/A. Avram/S. Dönmez/J. Hargrave (eds.): The Bosporus : Gateway between the Ancient West and East ( $1^{\text {st }}$ Millennium BC-5 $5^{\text {th }}$ Century AD). Proceedings of the Fourth International Congress on Black Sea Antiquities. Istanbul, $14^{\text {th }}-18^{\text {th }}$ September 2009. BAR International Series 2517. Oxford 2013, 19-21. 
Bouzek et al. 2017

Bouzek/Domaradzka 2009

Božkova 2002

Božkova 2005

Božkova 2015

Božkova/Nikov 2004/2006

Catling 1998

Coja/Dupont 1979

Cook/Dupont 1998

Crişan 1969

Domaradzki 2002

Dupont 1983

Dupont 2001

Dupont/Baralis 2014

Gebauer 1993

Chabot Aslan 2009

Kopylov 2009

Metzner-Nebelsick 2017

Miroššayová 1998

Miroššayová 2017
J. Bouzek/M. Pecinovská/J. Ř́ídký/P. Sankot: Bemerkungen zur keltischen Kunst und zu mediterranen Importen der Frühlatènezeit in Böhmen. Studia Hercynia 21, 2017, 46-75.

J. Bouzek/L. Domaradzka: Thracian Grey Ware in Bulgaria: Pistiros and other sites. In: A. Avram et al. (eds.): Pontic Grey Wares 2009. International Conference. Bucarest-Constantza September $30^{\text {th }}$-October $3^{\text {rd }}$ 2008. Pontica 42. Suppl. 1. Constanţa 2009, 199-222.

A. Božkova: Pottery with Geometric decoration and related wares. In: A. Božkova/P. Delev (eds.): Koprivlen I. Rescue Archaeological Investigations along the Gotse Delchev - Drama Road 1998-1999. Sofia 2002, 133-144.

A. Božkova: Greek Archaic pottery at Koprivlen. In: J. Bouzek/L. Domaradzka (eds.): The Culture of Thracians and Their Neighbours. Proceedings of the International Symposium in Memory of Prof. Mieczyslaw Domaradzki with a Round Table "Archaeological Map of Bulgaria". BAR International Series 1350. Oxford 2005, 85-90.

A. Božkova: The pottery in Ancient Thrace. In: J. Valeva/D. Graninger/E. Nankov (eds.): Companion to Ancient Thrace. Chichester 2015, 229-243.

A. Božkova/K. Nikov: La céramique monochrome en Thrace et ses prototypes anatoliens. Problèmes de chronologie. Il Mar Nero 6, 2004/2006, 47-56.

R. W. V. Catling: The typology of the Protogeometric and Subprotogeometric Pottery from Troia and its Aegean context. Studia Troica 8, 1998, 151-187.

M. Coja/P. Dupont: Histria V. Ateliers céramiques. Bucureşti 1979.

J. Cook/P. Dupont: East Greek Pottery. London - New York 1998.

I. H. Crişan: Ceramica daco-getică: cu speciala privire la Transilvania. Bucureşti 1969.

M. Domaradzki: Grey Pottery from Pistiros. Part I. In: J. Bouzek/L. Domaradzka/Z. H. Archibald (eds.): Pistiros 2: Excavations and Studies. Prague 2002, 189-208.

P. Dupont: Classification et détermination de provenance des céramiques grecques orientales archaïques d'Istros. Rapport préliminaire. Dacia 27, 1983, $19-46$.

P. Dupont: Les ateliers primordiaux des coupes ioniennes à la lumière des trouvailles de la Mer Noire. In: Second International Congress on Black Sea Antiquities: Local Populations of the Black Sea Littoral and Their Relations with the Greek, Roman and Byzantine World and Near Eastern Civilisations. Abstracts. Bilkent University, Ankara, Turkey, 2-9 September 2001. Ankara 2001, 45-47.

P. Dupont/A. Baralis: Ateliers céramiques et résaux d'echange dans les SudOuest de la Mer Noire à l'époque classique et au début de l'époque hellénistique. Bulletin de Correspondence Hellénique 138, 2014, 387-428.

J. Gebauer: Verschiedene graue Waren. In: Ü. Serdaroglu/R. Stupperich (Hrsg.): Ausgrabungen in Assos 1991. Asia Minor Studien 10. Bonn 1993, 73100.

C. Chabot Aslan: Gray ware at Troy in the Protogeometric through Archaic periods. In: A. Avram et al. (eds.): Pontic Grey Wares 2009. International Conference. Bucarest-Constantza, September $30^{\text {th }}-$ October $3^{\text {rd }}$ 2008. Pontica 42. Suppl. 1. Constanţa 2009, 267-283.

V. P. Kopylov: La céramique grise des monuments des $\mathrm{VII}^{\mathrm{e}}-\mathrm{I}^{\mathrm{er}}$ tiers du $\mathrm{III}^{\mathrm{e}} \mathrm{s}$. av. J.C. à l'embouchure du Tanaïs. In: A. Avram et al. (eds.): Pontic Grey Wares 2009. International Conference. Bucarest-Constantza, September $30^{\text {th }}$-October $3^{\text {rd }}$ 2008. Pontica 42. Suppl. 1. Constanţa 2009, 191-196. .

C. Metzner-Nebelsick: Sumptuous Vessels and Animal Protomes - New finds of the early Hallstatt period in Southeast Pannonia. In: E. Miroššayová/Ch. Pare/S. Stegmann-Rajtár (Hrsg.): Das nördliche Karpatenbecken in der Hallstattzeit. Wirtschaft, Handel und Kommunikation in früheisenzeitlichen Gesellschaften zwischen Ostalpen und Westpannonien. Archaeolingua 38. Budapest 2017, 433-470.

E. Miroššayová: Podiel popolnicových polí na formovaní staršej doby železnej na východnom Slovensku. Východoslovenský pravek 5, 1998, 149-156.

E. Miroššayová: East Slovakia in the Hallstatt period - the current stage of knowledge. In: E. Miroššayová/Ch. Pare/S. Stegmann-Rajtár (Hrsg.): Das nördliche Karpatenbecken in der Hallstattzeit. Wirtschaft, Handel und Kommunikation in früheisenzeitlichen Gesellschaften zwischen Ostalpen und Westpannonien. Archaeolingua 38. Budapest 2017 311-334. 
Miroššayová/Pare/Stegmann-Rajtár 2017

Moscalu 1983

Nikov 2012

Romsauer 1991

Rotroff 2006

Sîrbu/Niculifä/Vanciugov 2005

Sparkes/Talcot 1970

Stegmann-Rajtár 2017

Trefný/Slabina 2015

Vančugov 2001
E. Miroššayová/Ch. Pare/S. Stegmann-Rajtár (Hrsg.): Das nördliche Karpatenbecken in der Hallstattzeit. Wirtschaft, Handel und Kommunikation in früheisenzeitlichen Gesellschaften zwischen Ostalpen und Westpannonien. Archaeolingua 38. Budapest 2017.

E. Moscalu: Ceramica traco-getică. Bucureşti 1983.

K. Nikov: Grey Monochrome pottery from Apollonia Pontica. On its Origin and Initial Distribution (late VII ${ }^{\text {th }}-V I^{\text {th }}$ century BC). Veliko Tarnovo 2012.

P. Romsauer: The earliest wheel-turned pottery in the Carpathian Basin. Antiquity 65, 1991, 358-387.

S. I. Rotroff: Hellenistic Pottery: The Plain Wares. The Athenian Agora 33. New Jersey 2006.

V. Sîrbu/I. Niculifä/V. Vanciugov: Le sud de Budgeac au Irr millénaire av. J.-C. (découvertes archéologiques et interprétations historiques). In: J. Bouzek/L. Domaradzka (eds.): The Culture of Thracians and Their Neighbours. Proceedings of the International Symposium in Memory of Prof. Mieczyslaw Domaradzki with a Round Table "Archaeological Map of Bulgaria". BAR International Series 1350. Oxford 2005, 51-68.

B. A. Sparkes/L. Talcott: Black and Plain Pottery of the $6^{\text {th }}, 5^{\text {th }}$ and $4^{\text {th }}$ Centuries B.C. The Athenian Agora XII. Princeton 1970.

S. Stegmann-Rajtár: Zur Abfolge der Osthallstatt- und der VekerzugKultur : Ein Überblick zum Forschungsstand der Hallstattzeit in der Südwestslowakei. In: E. Miroššayová/Ch. Pare/S. Stegmann-Rajtár (Hrsg.): Das nördliche Karpatenbecken in der Hallstattzeit. Wirtschaft, Handel und Kommunikation in früheisenzeitlichen Gesellschaften zwischen Ostalpen und Westpannonien. Archaeolingua 38. Budapest 2017, 383-402.

M. Trefný/M. Slabina: K nejdůležitějším aspektům architektury, hmotné kultury a k významu halštatského hradiště v Minicích (Kralupy nad Vltavou, okr. Mělník). Archeologické rozhledy 67, 2015, 45-78.

V. Vančugov: Belozerskie pogrebenija kurgannogo mogil'nika Alkalija. In: Davnja istorija Ukraïny i sumižnych regioniv. Juvilejnyj zbirnyk na čest' 70-riččja vid dnja narodžennja profesora Eduarda Al'bertoviča Balaguri. Carpatica-Karpatika 13. Užgorod 2001, 78-83.

\title{
Co inspirovalo vekerzugskou keramiku?
}

\author{
Ja n B ouzek
}

Souhrn

Příspěvek je věnován problému předloh vekerzugské keramiky točené na kruhu známých z okruhu šedých keramik severozápadního Černomoří a východního Balkánu, vyráběných na kruhu i v ruce. Vysvětlení tohoto jevu lze najít $\mathrm{v}$ inspiraci šedou keramikou v Egeidě zvanou aiólskou a v tzv. kuchyňském zboží 9.-7. století před n. 1. v řeckých poleis. Jejich technika výroby a tvary bylo daleko snadněji přebíratelné než sofistikovaná technika firnisových a malovaných váz. Východní vlivy ve vekerzugské keramice byly ranější a vyspělejších tvarů než západnější okruh tzv. braubašského zboží, ale v obecnějším smyslu je šíření hrnčířského kruhu a vyspělejších tvarů, podobně jako tomu bylo i u kovových výrobků, součástí obecné koiné rané doby železné společné mírnému pásu evropskému spolu s vyspělejším Středomořím.

Obr. 1. Fragment vekerzugské amfory z Minic (foto V. Čistáková).

prof. PhDr. Jan Bouzek, DrSc.

Ústav pro klasickou archeologii

Filozofická fakulta Univerzity Karlovy

Celetná 20

CZ - 11000 Praha

jan.bouzek@ff.cuni.cz 